\title{
Penguatan Brand Personality Melalui Instagram Bagi Usaha Kecil Menengah (UKM) di Bandar Lampung
}

\author{
Mediya Destalia*, Damayanti, Jeni Wulandari, Hani Damayanti
}

IImu Administrasi Bisnis, Universitas Lampung, Bandar Lampung, 35145, Lampung, Indonesia

\begin{abstract}
Abstrak.
Di kota Bandar Lampung banyak sekali pelaku Usaha Kecil Menengah yang berberak di berbagai bidang, baik berupa barang maupun jasa. Produk usaha kecil dan menengah (UKM) memiliki banyak kesamaan. Untuk dapat pertahan di persaingan dunia usaha, maka diperlukan strategi pemsaran. Salah satunya yaitu dengan membuat brand personality sebagai strategi diferensasi positioning. UKM yang telah memiliki brand personality, maka akan lebih mudah dikenali, diingat dan diperhatikan oleh konsumen. Peserta pelatihan ini yaitu pelaku UKM yang ada di Bandar Lampung. Metode yang digunakan yaitu ceramah dan praktek. Pada kegiatan tersebut diketahui bahwa beberapa pelaku UKM sudah membuat brand personality namun belum dimanfaatkan sebagai strategi pemasaran. Jadi untuk para pelaku UKM yang telah memiliki brand personality sebaiknya selalu mengembangkan karakter produknya. Salah satu cara untuk memperkuat brand personality yaitu dengan memamfaatkan media social instagram. Dengan adanya pelatihan ini diharapkan para pelaku UKM mampu membuat brand personality dan memperkuat karakter usahanya. Sehingga usaha yang dikembangkan oleh pelaku UKM mampu bersaing di pasar dan bertahan untuk jangka waktu yang lama.
\end{abstract}

Kata kunci.

Brand, UKM, Personality.

\section{PENDAHULUAN}

Kota Bandar lampung merupakan ibukota propinsi Lampung. Sebagai ibukota propinsi, Bandar lampung dijadikan sebagai salah satu kota penggerak perekonomian lampung. Salah satu sektor penggerak perekonomian di Bandar Lampung yaitu Usaha Kecil Menengah (UKM). Berdasarkan data dari dinas koperasi dan UKM, jumlah UMKM yang ada di Bandar Lampung berjumlah 46.324.

UKM di Bandar lampung bergerak diberbagai sektor, baik sektor barang maupun sektor jasa. Sektor UKM yang sangat banyak, maka mengakibatkan banyak jenis usaha UKM yang sama. Misalnya banyak UKM yang bergerak di bidang makanan keripik pisang, kedai kopi,

* Corresponding author: mediya.destalia@fisip.unila.ac.id

Received 16 November 2020; Received in revised form 27 November 2020; Accepted 7 December 2020

Available online 24 December 2020

Lembaga Penelitian dan Pengabdian Kepada Masyarakat

Universitas Lampung 
pempek dan lain sebagainya. Selain itu di bidang jasa missal makeup artist (MUA). Dikarenakan banyak produk yang sama, maka UKM dituntut agar mampu bersaing. Salah satu strategi bersaing yang harus dilakukan oleh UKM yaitu penguatan karakter produk. Penguatan karakter ini dialkukan dengan memiliki brand personality.

Brand personality yaitu membuat identitas produk dengan cara mengasosiasikan karakter manusia kedalam produk [1]. Brand personality biasanya disesuaikan dengan karakter pelaku UKM. Dengan memeiliki brand personality, maka akan memudahkan pelanggan untuk memilih produk yang dibutuhkan sesuai dengan pilihannya.

Menurut Aaker [1], dalam membangun hubungan emosional dengan para konsumen maka harus memanfaatkan karakteristik manusia sebagai salah satu identitas merek dan dengan brand personality, maka merek yang dimiliki mampu dibedakan dan bersaing dengan merek pesaingnya. Jadi dalam menetapkan strategi pemasaran, seorang pelaku UKM harus mampu membaca perilaku konsumen.

Perilaku konsumen sebagai proses yang dilalui oleh seseorang dalam mencari, membeli, menggunakan, mengevaluasi, dan bertindak pasca konsumsi produk, jasa maupun ide yang diharapkan bisa memenuhi kebutuhannya. Jadi, dapat dikatakan bahwa perilaku konsumen adalah studi tentang bagaimana individu, atau kelompok dalam membuat keputusan untuk melakukan pembelian produk dan kemudian mengkonsumsinya.

Pada beberapa penelitian yang mengatakan bahwa brand personality mampu menggerakkan konsumen untuk melakukan pembelian. Seperti penelitian yang dilakukan oleh Priscilla yang mengatakan bahwa brand personality berpengaruh signifikan terhadap minat beli konsumen. Penelitian lain oleh Naibaho dan Lili [2] yang mengatakan bahwa brand personality berpengaruh signifikan pada minat beli.

Mengingat pentingnya brand personality dalam menarik minat beli konsumen, maka perlu promosi yang terus menerus agar memperkuat posisi brand UKM di pelanggannya. Salah satu upaya yang dapat dilakukan yaitu melaui pemanfaatan mdia social, salah satunya yaitu instagram. Dengan selalu meyebutkan brand personality di tiap keterangan produk, maka akan selalu mengingatkan para konsumen dengan produk UKM tersebut.

Berdasarkan latar belakang tersebut maka tujuan pengabdian yaitu membangun karakter usaha dan produk UKM melalui Brand Personality dan memperkuat positioning melalui instagram.

\section{METODE}

Dalam kegiatan ini akan diterapkan pelatihan dengan metode ceramah dan praktik.

1. Pendekatan ceramah dilakukan untuk memberikan pemahaman kepada pelaku UKM tentang pentingnya brand personality untuk meningkatkan minat beli konsumen.

2. Pendekatan Praktik dilakukan untuk mengajarkan secara langsung tentang pembuatan brand personality dan memanfaatkan aplikasi instagram untuk memperkenalkan dan memperkuat brand personality.

\section{HASIL DAN PEMBAHASAN}

Pelaksanaan kegiatan ini diinisiasi berdasarkan hasil wawancara dengan beberapa alumni yang telah menjadi wirausaha. Dari hasil wawancara tersebut didapatkan data bahwa pelaku UKM belum memahami pentingnya brand personality bagi keberlangsungan usahanya. Hal ini juga terlihat dari hasil pre-test yang dilakukan sebelum penyampaian materi.

Peserta belum mampu menjelaskan secara tepat yang dimaksud dengan brand personality. Banyak peserta yang terkecoh dengan personal branding. Perbedaan antara brand personality dengan personal branding yaitu antara lain: 
1. Brand personality yaitu citra diri produk sedangkan personal branding yaitu citra diri pelaku usaha.

2. Brand personality mengasosiasi karakter manusia kedalam produk. Sedangkan personal branding menggunakan diri atau karir pelaku usaha sebagai merek.

Brand personality merupakan identitas dari produk maupun usaha yang dilakukan oleh para pelaku UKM. Jadi brand personality ini mengacu pada karakteristik dari pelaku UKM yang tercermin pada suatu merek. Biasanya brand personality ini terbentuk dari bagai-mana seseorang tersebut ingin dilihat oleh orang lain. Hal itulah yang kemudian dikembangkan menjadi brand personality.

Meskipun para pelaku UKM belum mampu menjelaskan mengenai brand personality, namun pada dasarnya secara praktek para pelaku UMKM telah memiliki brand personality untuk masing-masing bisnisnya. Namun mereka tidak mengetahui bahwa itulah yang dimaksud dengan brand personality. Hal ini dapat terlihat dari berbagai Instagram (IG) peserta UKM.

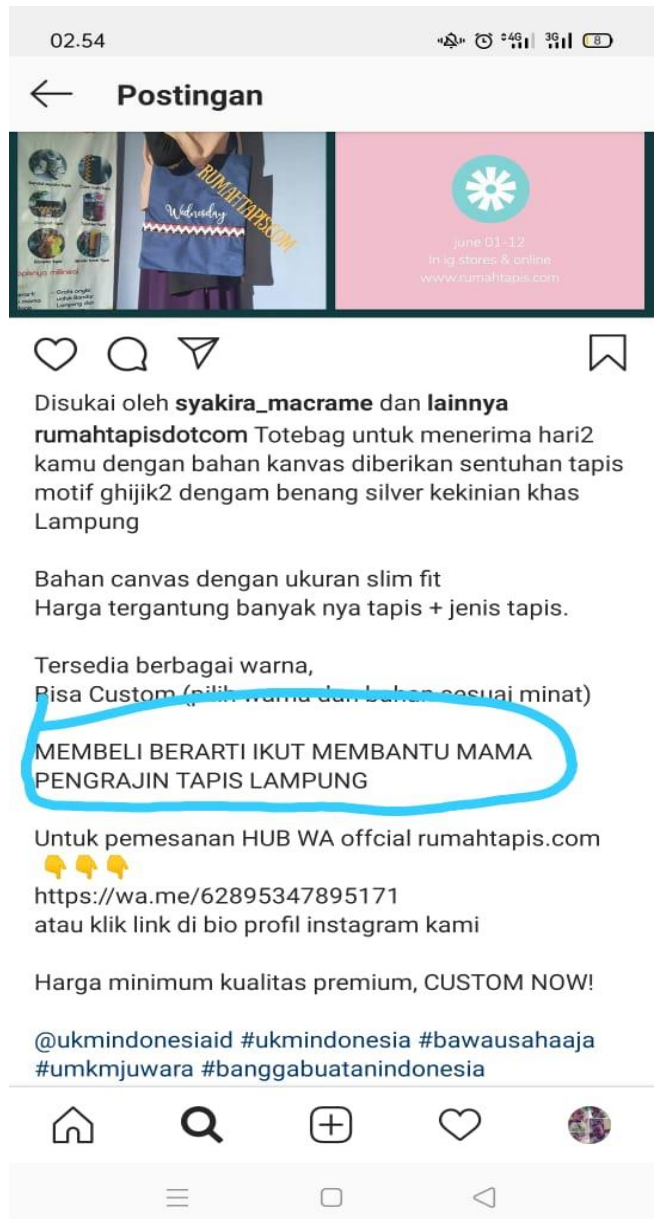

Gambar 1. Instagram rumahtapis.com.

Pada Gambar 1, pelaku UKM selalu menyebutkan brand personality nya di dalam keterangan produk. Dengan kalimat "membeli berarti membantu mama pengrajin tapis lampung", menjelaskan bahwa karakter dari produk yang dijual yaitu produk yang ingin melestarikan kebudayaan daerah dan membantu produk lokal untuk berkembang. Hal ini ini menjelaskan kepada para pelanggannya bahwa pelaku UKM menghargai produk daerah/lokal.

Pernyataan pada gambar 1 tersebut sejalan dengan pengertian brand personality menurut Armstrong dan Kotler yang menyebutkan bahwa brand personality merupakan gabungan sifat masunia yang diasosiasikan ke dalam merek/produk. 


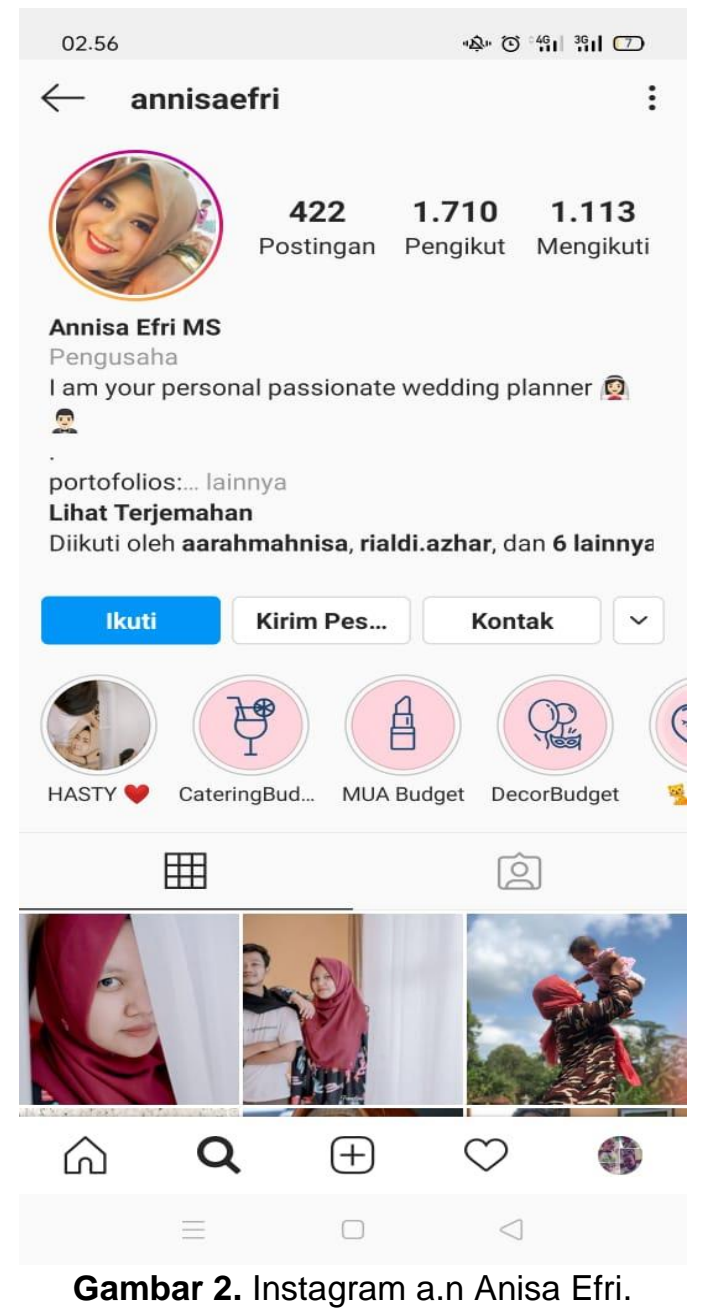

Berdasarkan gambar 2, diketahui bahwa usaha yang dijalankan merupakan dibidang jasa, yaitu wedding planner.

Perbedaan yang terlihat dari gambar 1 dan gambar 2 yaitu lokasi penyebutan brand personality. Pada gambar 1, brand personality disebutkan di dalam keterangan produk, sedangkan di gambar 2 brand personality disebutkan di halaman muka istagram.

Dari kedua gambar tersebut kita dapat melihat 2 dimensi yang berbeda. Berdasarkan penelitian Aaker [1] sesungguhnya di dalam brand personality memiliki 5 dimensi yang mencirikan karakteristiknya seperti terlihat pada gambar berikut:

\section{BRAND PERSONALITY FPMMEWORK}

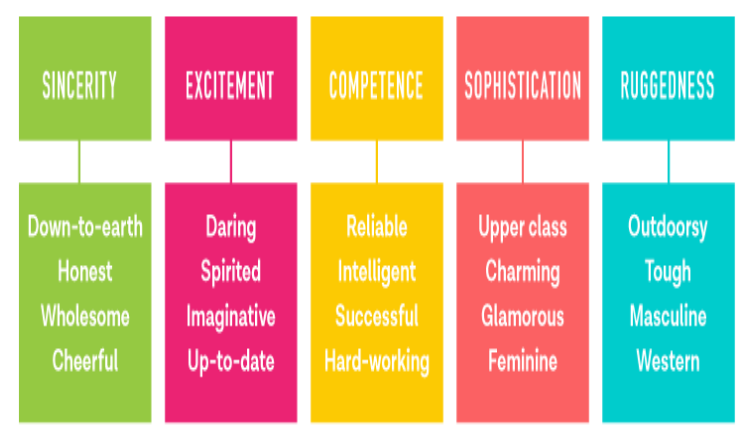

Gambar 3. Model Aaker.

Selanjutnya Armstrong dan Kotler menjelaskan mengenai five brand personality traits 
sebagai berikut:

1. Sincerity (ketulusan) karakter yang jujur, rendah hati, dan sederhana. Sincerity tertuang dalam kejujuran dalam kualitas, keaslian produk, dan keidentikan merek dengan sifat-sifat yang sederhana, seperti ceria dan berjiwa muda.

2. Excitement (semangat) berarti karakter unik yang penuh semangat dan imajinasi yang tinggi dalam melakukan perbedaan dan inovasi.

3. Competence (kemampuan), yaitu keamanan, kemudahan, kemampuan untuk dapat diandalkan dan dipercaya oleh pelanggan.

4. Sophistication (keduniawian), yaitu karakteristik yang berkaitan dengan eksklusifitas yang dibentuk oleh keunggulan prestise, citra merek, maupun tingkat daya tarik yang ditawarkan pada pelanggan.

5. Ruggedness (ketangguhan), yaitu karakteristik merek yang dikaitkan dengan kemampuan suatu merek dalam menunjang kegiatan luar rumah dan kekuatan atau daya tahan produk.

Setelah mengetahui dimensi karakter dari brand personality, maka kita akan mampu mengelompokkan bahwa gambar 1 merupakan contoh brand personality dengan dimensi sincerity (ketulusan). Sedangkan gambar 2 merupakan contoh brand personality dengan karakter competence (kemampuan) karena dengan kalimat "I am your personal passionate wedding planner" terdapat kepercayaan diri yang tinggi dari pelaku UKM. Sehingga konsumen akan percaya dengan kualitas jasa yang akan diberikan.

Selain itu, peserta pelatihan juga belum memahami pentingnya brand personality. Dengan brand personality yang telah dibuat oleh para pelaku, seharusnya dapat dimanfaatkan untuk membuat strategi pemasaran yang tepat. Sehingga broduk atau bisnis UKM nya selalu diingat oleh para konsumen maupun calon konsumen.

Seperti yang dijelaskan oleh beberapa penelitian naiboho dan lili [2] yang menyebutkan bahwa ada pengaruh yang signifikan anatara brand personality dengan minat beli konsumen. Menurut Sirgy mengatakan bahwa konsumen seringkali memilih mereks dengan brand personality yang konsisten dengan karakter dirinya. Konsep kepribadian/karakter dapat menjadi salah satu variable yang mendorong minat beli konsumen serta mendorong konsumen untuk menetukan pilihan merek yang berkaitan dengan perilaku konsumen [3].

Minat beli merupakan perilaku konsumen yang menunjukkan besarnya komitmen pelanggan untuk melakukan pembelian. Sehingga membangun minat beli konsumen menjadi hal yang penting karena dapat menarik konsumen untuk melakukan keputusan pembelian terhadap suatu produk. Keller [4] mengatakan bahwa minat beli konsumen merupakan adanya peluang atau kemungkinan konsumen untuk membeli suatu merek atau seberapa beasr kemungkinan konsumen kana berpindah dari produk satu ke produk lainnya.

Dengan melihat teori tersebut, pelaku UKM dituntut agar dapat mempertahankan dan menciptakan pelanggan loyal. Brand personality dapat dijadikan salah satu alternative strategi untuk mempertahankan konsumen yang sudah ada dan menarik konsumen potensial.

Adapun alasan mengapa pelaku UKM dituntut untuk membuat brand personality karena brand personality berguna untuk:

1. Membedakan dari kompetitor.

Artinya, dengan ciri khas yang dimiliki, dapat membedakannya dengan kompetitor lainnya.

2. Menentukan konteks.

Hal ini tidak dapat dipisahkan dari sasaran konsumen atau segmen pasar yang akan disasar agar jasa pelayanan Anda tepat sasaran. 
3. Membangun komunikasi yang konsisten Membangun komunikasi yang konsisten dengan konsumen terkait personality yang dibangun agar konsumen tetap ingat dengan jasa pelayanan yang ditawarkan.

4. Membangun ekuisitas dalam waktu lama. Hal ini dibutuhkan agar brand personality yang dibangun dapat bertahan lama dan langgeng serta tetap kokoh dengan personality yang dimilikinya.

Salah satu pendorong utama dari terbentuknya kepribadian merek adalah karakteristik dan kualitas barang atau jasa. Kepribadian merek dibentuk oleh karakter-karakter yang terkait dengan barang atau jasa maupun karakter-karakter yang tidak berkaitan dengan barang atau jasa. Salah satu caranya adalah dengan sedapat mungkin menyesuaikan brand personality dengan konsumen, semakin dekat kepribadian yang dimiliki konsumen, akan lebih baik. Proses pembentuk brand personality menurut buku Asian Branding adalah sebagai berikut:

1. Mendefinisikan pasar sasaran

2. Menemukan apa yang mereka butuhkan inginkan, dan mereka sukai

3. Membuat profil kepribadian konsumen.

4. Menciptakan brand personality yang sesuai dengan profil perusahaan.

Brand personality merupakan salah satu strategi pemasaran yang cukup ampuh dalam positioning. Jika merek yang dikembangkan telah memiliki karakter tersendiri, dan dengan konsisten mampu mendefinisikan ciri merek, maka dapat dikatakan bahwa pelaku usaha tersebut telah mampu memanfaatkan personal branding ini dengan tepat. Jika sudah dilakukan terus menerus, maka akan memudahkan para konsumen dan calon konsumen untuk mengenali, mengingat dan memperhatikan produk yang dimiliki.

Dengan kata lain, brand personality dapat membantu sebuah merek dalam memahami persepsi konsumen dan juga sikap mereka terhadap merek, memberikan brand identity yang berbeda, menjaga komunikasi merek, dan menciptakan brand equity. Menurut Aaker [5] terdapat empat manfaat brand personality, yaitu:

1. Meningkatkan pemahaman.

2. Memberikan brand identity yang berbeda.

3. Menjaga usaha komunikasi merek.

4. Menciptakan brand equity.

Para peserta pelatihan merupakan pelaku usaha UMKM. Beberapa usaha yang dijalankan oleh para peserta memiliki kemiripan produk. Dengan adanya pelatihan ini, maka akan membantu para pemilik UMKM agar mampu bersaing dan mampu mempertahankan usahanya. Dengan brand personality yang jelas, maka strategi diferensiasi produk maka tiap usaha yang dijalankan memiliki tempat (positioning) di pikiran para pelanggannya.

\section{KESIMPULAN}

Kesimpulan dari kegiatan pengabdian ini yaitu:

1. Banyak pelaku UKM yang belum memiliki pemahaman tentang brand personality

2. Tanpa pengetahuan yang jelas tantang brand personality, namun beberap pelaku UKM telah memiliki brand personality tersebut.

3. Melalui pelatihan tentang brand personality untuk UKM mampu meningkatkan pengetahuan pelaku UKM

4. Pelaku UKM dapat membuat strategi pemasaran melalui brand personality

5. Brand personality dapat semakin diperkuat dengan adanya bantuan teknologi yang dapat membantu proses penyampaian brand personality kepada konsumen 
6. Brand personality dapat meningkatkan minat beli konsumen.

\section{DAFTAR PUSTAKA}

[1] Aaker, Jennifer L. 1997. Dimensions of Brand Personality. Journal of Marketing Research, 34, 347356.

[2] Naibaho, Agnes, Ai Lili Lili Yuliati. 2017. Pengaruh Brand Personality Terhadap Minat Beli Produk Body Mist (Studi pada The Body Shop di Trans Studio Mall Bandung). http://www.jurnal.stmikmi.ac.id/index.php/jcb/article/view/155 tanggal 20 September 2020.

[3] Kotler, P., \& Keller, K. L. (2012). Marketing Management 14e Edition, New Jersey: Person Education, Inc.

[4] Keller, K. L. (2012). Strategic Brand Management (4th edition). England: Pearson Prentice Hall.

[5] Aaker, D.A., \& Joachimsthaler, E. (2000). Brand Leadership. New York : The Free Press. 